\title{
ANALISIS KINERJA APARATUR DAN PELAYANAN PUBLIK SEBAGAI DASAR MENUJU REFORMASI BIROKRASI YANG IDEAL (Study Kasus Pemerintah Kota Jambi)
}

\author{
Oleh: \\ *) Ahmad Soleh, S.E., M.E. \\ *) Iwan Eka Putra, S.E., M.M. \\ *) Yunie Rahayu, S.E., M.E. \\ *) Dosen Tetap STIE Muhammaadiyah Jambi
}

\begin{abstract}
Abstrak
Didasarkan pada kondisi birokrasi saat ini yang masih belum efisien dan efektif dengan berbagai macam permasalahan maka, sangat perlu dilakukan perubahan yang mendasar baik dalam efisiensi dan efektifitas pelayanannya.

Tujuan yang ingin dicapai dari penelitian ini adalah menganalisis mengenai kinerja aparatur dan pelayan publik pemerintah di Kota Jambi, sebagai indikator kelayakan kinerja aparatur dan pelayanan publik untuk bahan acuan pertimbangan pengambilan keputusan dalam revormasi birokrasi di Kota Jambi. Penelitian ini lakukan pada seluruh instansi pada SKPD di pemerintah Kota Jambi yang dilakukan dengan menggunakan metode deskriptif kualitatif. Data yang digunakan dalam penelitian ini adalah data sekunder yang dikumpulkan dari seluruh instansi yang ada di Pemeritah Kota Jambi, dan literatur-literatur serta jurnal jurnal yang diperlukan. Model analisis yang digunakan adalah model indek kinerja yang diadopsi dari perhitungan yang digunakan Bappenas bekerja sama dengan UNDP, yang selanjutnya diteruskan dengan analisis SWOT dengan menganalisa faktor internal dan eksternal dalam menyusun strategi melalui Strength-Opportunities (SO), WeaknessOpportunities (WO), Strengths-Threats (ST) dan Weaknesses-Threats (WT).

Hasil penelitian ini menunjukkan bahwa Kinerja Pelayanan aparatur pada pemerintah Jambi sangat baik dan Kinerja Pelayanan publik pada pemerintah Jambi juga sangat baik.
\end{abstract}

Kata Kunci: Kinerja aparatur dan pelayanan publik, Analisis SWOT, reformasi birokrasi

\section{Pendahuluan}

Secara filosofis, keberadaan pemerintah adalah untuk memberikan pelayanan kepada rakyat melalui berbagai aktivitasnya. Penyelenggaraan pemerintahan menyangkut penyelenggaraan administrasi pemerintahan sehari-hari (day to day administrator) secara luas, pemberian pelayanan kepada masyarakat luas (public services) serta pembangunan berbagai infrastruktur maupuan fasilitas yang dibutuhkan oleh masyarakat. Penyelenggaraan pemerintahan harus mampu mengatasi persoalan-persoalan riil yang dihadapi masyarakat, setidaknya memberikan fasilitas secara maksimal sehingga masyarakat mampu mengatasi persoalan-persoalan yang dihadapinya.

Pengelolaan pemerintahan pada saat ini sedang berada pada masa transisi. Beberapa penanda yang dapat diamati adalah adanya pergeseran paradigma pengelolaan pemerintahan dari yang berbasis pada kekuasaan ke arah manajemen publik yang berdasarkan pada 
akuntabilitas (accountability) dan pemenuhan kepuasan penggunan layanan (customer satisfaction). Peran pemerintah sebagai penyelenggara seluruh kegiatan (acting or executing) berubah menuju ke peran sebagai pengarah (regulating) dalam rangka pemberdayaan (empowering) masyarakat. Selain itu, pengelolaan pemerintahan yang berstruktur dan berbudaya tertutup bergeser menuju ke arah pengelolaan yang terbuka (transparency).

Aparatur pada hakekatnya merupakan hal-hal yang berkenaan dengan kedudukan, tugas, hak, wewenang, dan tanggung jawab selaku penyelenggara negara. Aparatur sebagai subyek dan obyek penyelenggaraan negara dan pemerintahan memegang peran penting diantara sumber daya lainnya, baik berdasar dimensi organisasi maupun manajemen. Untuk memperkuat itu dan dalam upaya mewujudkan masyarakat madani yang taat hukum, berperadaban modern, demokratis, makmur, adil dan bermoral tinggi, diperlukan aparatur yang profesional yaitu aparatur yang bertugas sebagai abdi masyarakat dengan tuntutan dapat memberikan pelayanan yang baik, jujur, adil, merata, dan tidak diskriminatif serta mampu menjaga persatuan dan kesatuan. Merujuk pada uraian ini, manajemen sumberdaya manusia aparatur diperlukan sebagai landasan pengelolaan aparatur. Kebijakan mengenai manajemen sumber daya manusia aparatur seyogyanya mencakup keseluruhan upaya-upaya untuk meningkatkan efisiensi efektivitas, derajat profesionalisme penyelenggaraan tugas, fungsi, dan kewajiban aparatur, yang antara lain meliputi tahapan perencanaan, pengadaan pengembangan kualitas, penempatan, promosi, penggajian, kesejahteraan dan pemberhentian.

Sebagai gambaran kinerja aparatur pemerintah di Indonesia dibandingkan dengan negara-negara lain di ASEAN dalam hal pengurusan perizinan masih sangat memakan waktu. Pengurusan perizinan untuk usaha di Singapura dan Thailand hanya memerlukan waktu 3 hari, sementara perizinan di Indonesia memerlukan waktu 60 hari atau bahkan lebih lama. Secara lengkapnya dapat dilihat pada tabel di bawah ini.

Tabel 1. Lamanya Hari Dalam Prosedur Pembuatan Izin Usaha Negara ASEAN.

\begin{tabular}{|l|c|c|c|c|}
\hline Negara & $\begin{array}{c}\text { Jumlah } \\
\text { prosedur } \\
\text { memulai bisnis }\end{array}$ & $\begin{array}{c}\text { Jumlah Hari } \\
\text { Memulai } \\
\text { Bisnis }\end{array}$ & $\begin{array}{c}\text { Biaya (\% dari } \\
\text { Pendapatan Per } \\
\text { Kapita) }\end{array}$ & $\begin{array}{c}\text { Modal Minimal } \\
\text { (\% dari Pendapatan } \\
\text { Per Kapita) }\end{array}$ \\
\hline Singapore & 3 & 3 & 0,7 & 0 \\
\hline Thailand & 3 & 3 & 6,3 & 0 \\
\hline Indonesia & 9 & 60 & 26 & 59,7 \\
\hline Kambodia & 9 & 85 & 138,4 & 36,3 \\
\hline Malaysia & 9 & 11 & 11,9 & 0 \\
\hline Timur Leste & 10 & 83 & 4,1 & 0 \\
\hline Vietnam & 11 & 50 & 13,3 & 5,5 \\
\hline Fhilipina & 15 & 42 & 28,2 & 15,5 \\
\hline Rata Rata OECD & 5,7 & 13 & 4,7 & 21,3 \\
\hline Asia Fasifik & 8,1 & 41,1 & 25,8 & \\
\hline
\end{tabular}

Sumber: Surat Edaran Ditjen Bina Bangda Depdagri. 
Masalah pelayanan terutama dalam organisasi publik telah menjadi sebuah isu yang krusial. Dalam penyelenggaraan pelayanan publik, aparatur pemerintah bertanggung jawab untuk memberikan pelayanan yang terbaik sesuai dengan kebutuhan masyarakat. Pentingnya kualitas pelayanan mendapat perhatian, karena disatu sisi tuntutan masyarakat terhadap perbaikan kualitas semakin gencar, namun disisi lain kesiapan dan perbaikan belum menunjukkan kemajuan berarti. Salah satu faktor penting agar dapat diselenggarakan pelayanan yang berkualitas adalah adanya budaya pelayanan yang berorientasi kepada kepentingan masyarakat atau pengguna jasa.

Berdasarkan uraian latar belakang diatas maka tujuan dari penelitian ini adalah: (1) Untuk menganalisis kinerja aparatur dan pelayanan publik pada pemerintah Kota Jambi; (2) Untuk menganalisis strategi yang paling tepat dalam melakukan revormasi birokrasi pada pemerintah Kota Jambi.

\section{Metode Penelitian}

Metode penelitian yang digunakan dalam penelitian ini adalah metode Deskriptif dan metode Kuantitatif dengan menggunakan data sekunder dan tehnik penugmpulan pooling data yang dilaksanakan di lingkungan pemerintah Kota Jambi.

\section{Metode Analisis Data}

\section{Model Analisis Pertama}

Untuk menghitung berapa besar tingkat kinerja aparatur pemerintah dipemerintah Kota Jambi menggunakan model Indeks Kinerja diadopsi dari Badan Perencanaan Nasional (Bappenas) bekerjasama dengan United Nations Development Programme (UNDP) Tahun 2008 dengan rumus sebagai berikut:

$\begin{aligned} \text { IKAPD } & =\text { Indeks Kinerja Aparatur Pemerintah Daerah } \\ & =\frac{\text { IKAPD }=\text { PASTA }_{i, t}+\text { PAPTA }_{i, t}+\text { PARTA }_{i, t}}{3} \\ \text { PASTA }_{i, t}= & \text { Persentase aparatur sarjana per total aparatur } \\ & \text { PASTA }=\frac{\text { Jumlah aparatur yang berpendidikan min. sarjana }}{\text { Jumlah aparatur secara keseluruhan }} \\ \text { PAPTA }_{i, t}= & \text { Persentase aparatur pendidik pertotal aparatur } \\ & \text { PAPTA }=\frac{\text { Jumlah aparatur pendidik }}{\text { Jumlah Aparatur secara keseluruhan }} \\ \text { PARTA }_{i, t}= & \text { Persentase aparatur paramedis pertotal aparatur } \\ & \text { PARTA }=\frac{\text { Jumlah aparatur paramedis }}{\text { Jumlah Aparatur secara keseluruhan }} \\ & \end{aligned}$


Berikut dibuat kriteria yang digunakan dalam menginterprestasikan hasil Indeks Kinerja Aparatur yaitu dengan cara sebagai berikut:

a) Langkah pertama, membuat asumsi nilai ideal pada setiap indikator, berdasarkan data Badan Kepegawaian Negara (BKN) tahun 2013, sebagai berikut :
1. Aparatur Sarjana
Nilai ideal
44,43
2. Aparatur Pendidik
Nilai ideal $=42,58$
3. Aparatur Paramedis
Nilai ideal $=$
7,50

b) Langkah kedua, mencari nilai rata rata atas semua asumsi nilai ideal dari kelima indikator, yaitu :

Rata rata $=44,43+42,58+7,50=31,50$

c) Langkah ketiga, mencari interval kelas untuk masing masing kategori dengan menggunakan rumus statistik yaitu nilai rata-rata dibagi dengan kategori yang ingin digunakan. Dalam hal ini peneliti menggunakan 5 kategori yaitu kategori tidak baik, kurang baik, cukup baik, baik dan sangat baik, selanjutnya akan didapatkan interval masing masing kategori yaitu sebesar 6,30.

d) Langkah keempat, membuat kategori berdasarkan langkah-langkah diatas sehingga didapatkan hasil sebagai berikut :

Tabel 2. Kategori Kinerja Aparatur.

\begin{tabular}{|l|c|}
\hline \multicolumn{1}{|c|}{ Kategori } & Kinerja Aparatur \\
\hline Tidak Baik & $<12,60$ \\
\hline Kurang Baik & $12,60-18,90$ \\
\hline Cukup Baik & $18,90-25,20$ \\
\hline Baik & $25,20-31,50$ \\
\hline Sangat Baik & $>31,50$ \\
\hline
\end{tabular}

Untuk menganalisis berapa besar tingkat kinerja pelayanan publik di Pemerintah Kota Jambi menggunakan model Indek Kinerja Pelayanan Publik, berupa perhitungan yang diadopsi dari Badan Perencanaan Nasional (Bappenas) bekerjasama dengan United Nations Development Programme (UNDP) Tahun 2008 dengan formula sebagai berikut:

$$
\mathrm{IKPP}=\frac{\mathrm{DTSDP}_{\mathrm{i}, \mathrm{t}}+(100-\mathrm{RSDPG})_{\mathrm{i}, \mathrm{t}}+\mathrm{DTSLA}_{\mathrm{i}, \mathrm{t}}+\left(100-\mathrm{RSLAG}_{\mathrm{i}, \mathrm{t}}+\mathrm{KFK}_{\mathrm{i}, \mathrm{t}}\right.}{+\mathrm{KTK}_{\mathrm{i}, \mathrm{t}}+\mathrm{KI}_{\mathrm{i}, \mathrm{t}}}
$$

Dimana:

IKPP $\quad=$ Indeks Kinerja Pelayanan Publik

DTSDP $_{i, t}=$ Daya tampung siswa SD dan SLTP, nilai ini diperoleh dari :

DTSDP = Jumlah siswa SD dan SLTP (negeri \& swasta)

Jumlah sekolah SD \& SLTP (negeri \& swasta) 
$\mathrm{RSDPG}_{\mathrm{i}, \mathrm{t}}=$ Ratio murid SD dan SMP per guru, nilainya diperoleh dari :

$$
\mathrm{RSDPG}=\frac{\text { Jumlah siswa SD dan SLTP (negeri\&swasta) }}{\text { Jumlah guru SD \& SLTP (negeri\&swasta) }}
$$

Ratio murid SD-SLTP per guru terhadap beban guru bersifat negative artinya semakin besar nilainya semakin tidak baik bagi beban guru (menggambarkan ketidak efektifan proses belajar mengajar) dan sebaliknya, maka untuk menyamakan dengan variabel lainnya yang bersifat positif, harus dikonversi dengan mengurangkan angka 100 terhadap angka rasio murid SD-SLTP per guru agar bersifat positif.

DTSLA $_{i, t}=$ Daya tampung siswa SLTA, nilai ini diperoleh dari :

DTSLA $=$ Jumlah siswa SLTA (negeri\&swasta)

Jumlah sekolah SLTA (negeri\&swasta)

$\mathrm{RSLAG}_{\mathrm{i}, \mathrm{t}}=$ Ratio murid SLTA per guru, nilai ini diperoleh dari :

$$
\text { RSLAG }=\frac{\text { Jumlah siswa SLTA (negeri\&swasta) }}{\text { Jumlah guru SLTA (negeri\&swasta) }}
$$

Ratio murid SLTA per guru terhadap beban guru bersifat negatif artinya semakin besar nilainya semakin tidak baik bagi beban guru (menggambarkan ketidakefektifan proses belajar mengajar) dan sebaliknya, maka untuk menyamakan dengan variabel lainnya yang bersifat positif, harus dikonversi dengan mengurangkan angka 100 terhadap angka rasio murid SLTA per guru agar bersifat positif.

KFK $=$ Ketersediaan Fasilitas Kesehatan terhadap 10.000 penduduk, nilainya diperoleh dari :

$$
\mathrm{KFK}=\text { Jumlah rumah sakit, puskesmas, pustu, polindes }
$$
per 10.000 penduduk

KTK = Ketersediaan Tenaga Kesehatan terhadap 10.000 penduduk, nilainya diperoleh dari :

$$
\text { KFK = Jumlah Dokter, Perawat dan Bidan per } 10.000
$$

KI $=$ Kualitas Infrastruktur, nilainya diperoleh dari :

$$
\mathrm{KI}=\frac{\text { Panjang jalan dengan kondisi baik }}{\text { Total Panjang jalan keseluruhan }}
$$

Berikut dibuat kriteria yang digunakan dalam menginterprestasikan hasil Indeks Kinerja Pelayanan Publik yaitu dengan cara sebagai berikut : 
a) Langkah pertama, membuat asumsi nilai ideal pada setiap indikator, berdasarkan Rencana Strategi Dinas Pendidikan Tahun 2010-2014, Rencana Strategi Kementerian Kesehatan Tahun 2010-2014 dan Rencana Strategis Direktorat Jendral Bina Marga Tahun 2010 2014, sebagai berikut :

1. Daya tampung siswa SD dan SLTPNilai ideal $=300$

2. Daya tampung siswa SLTA Nilai ideal $=360$

3. Ratio murid SD dan SLTP Nilai ideal = 30,5

4. Ratio murid SLTA Nilai ideal $=21$

5. Ketersediaan fasilitas kesehatan Nilai ideal $=3,1$

6. Ketersediaan tenaga kesehatan Nilai ideal $=28,3$

7. Kualitas infrastruktur Nilai ideal $=60$

b) Langkah kedua, mencari nilai rata rata atas semua asumsi nilai ideal dari kelima indikator, yaitu :

Rata rata $=300+360+30,5+21+3,1+28,3+60=114,70$

c) Langkah ketiga, mencari interval kelas untuk masing masing kategori dengan menggunakan rumus statistik yaitu nilai rata-rata dibagi dengan kategori yang ingin digunakan. Dalam hal ini peneliti menggunakan 5 kategori yaitu kategori tidak baik, kurang baik, cukup baik, baik dan sangat baik, selanjutnya akan didapatkan interval masing masing kategori yaitu sebesar 22,94.

d) Langkah keempat, membuat kategori berdasarkan langkah-langkah diatas sehingga didapatkan hasil sebagai berikut :

Tabel 3. Kategori Kinerja Pelayanan Publik.

\begin{tabular}{|l|c|}
\hline \multicolumn{1}{|c|}{ Kategori } & Kinerja Aparatur \\
\hline Tidak Baik & $<45,88$ \\
\hline Kurang Baik & $45,88-68,82$ \\
\hline Cukup Baik & $68,82-91,76$ \\
\hline Baik & $91,76-114,70$ \\
\hline Sangat Baik & $>114,70$ \\
\hline
\end{tabular}

Model Analisis Kedua.

Untuk menganalisis strategi kebijakan yang paling tepat dalam upaya reformasi birokrasi di Kota Jambi, maka digunakan Matriks SWOT dilakukan dengan mengembangkan empat alternatif strategi berdasarkan kekuatan (strength), kelemahan (weakness), peluang (opportunity), dan ancaman (threat). Keempat alternatif strategi tersebut antara lain adalah 
strategi SO (strength-opportunity), strategi WO (weakness-opportunity), strategi ST (strengththreat) dan strategi WT (weakness- threat).

\section{Hasil Penelitian}

Kinerja Aparatur.

Anggaran Negara yang dibelanjakan untuk kepentingan pegawai dari tahun ke tahun selalu mengalami kenaikan, namun meningkatnya anggaran tersebut belum diimbangi dengan peningkatan profesionalisme dan integritas oleh para Pegawai Negeri Sipil. Belanja pegawai adalah semua pengeluaran negara yang digunakan untuk membiayai kompensasi dalam bentuk uang atau barang yang diberikan kepada pegawai pemerintah pusat, pensiunan, anggota Tentara Nasional Indonesia/ Kepolisian Negara Republik Indonesia, dan pejabat negara, baik yang bertugas di dalam negeri maupun di luar negeri, sebagai imbalan atas pekerjaan yang telah dilaksanakan, kecuali pekerjaan yang berkaitan dengan pembentukan modal.

Dalam kondisi ini, diperlukan metode yang tepat kepada para pengambil kebijakan dalam upaya meningkatkan profesionalisme kerja sehingga kinerja dari aparatur pemerintah dalam membangun daerah tersebut menjadi lebih baik. Perbaikan kondisi internal ini sekaligus bertujuan untuk membangun pondasi yang mendasar dalam mempercepat pembangunan ekonomi suatu daerah. Ini artinya instansi harus memperbaiki sistem manajemen kinerja instansinya melalui perbaikan kinerja pegawainya, karena keberhasilan instansi dalam memperbaiki kinerja instansinya sangat tergantung pada kualitas sumber daya manusia yang bersangkutan dalam berkarya atau bekerja.

Seperti yang kita ketahui bahwa kinerja adalah merupakan hasil atau tingkat keberhasilan seseorang secara keseluruhan selama periode tertentu dalam melaksanakan tugas dibandingkan dengan berbagai kemungkinan, seperti standar hasil kerja, target atau sasaran maupun kriteria yang ditentukan terlebih dahulu dan telah disepakati bersama. Faktor lain yang turut mempengaruhi baik atau tidaknya kinerja juga sangat dipengaruhi oleh kemampuan dan motivasi kerja oleh para aparatur, yang keduanya sangat sentral dalam proses peningkatan kualitas pelayanan. Artinya semakin baik kemampuan dan motivasi kerja seorang pegawai maka semakin baik kinerja yang dilakukan oleh pegawai tersebut demikian juga sebaliknya.

Berdasarkan data yang ada di Kota Jambi bahwa Jumlah Pegawai Negeri Sipil pada tahun 2014 sebanyak 2.980 pegawai dan mengalami penurunan menjadi 2102 pegawai pada tahun 2015. Penurunan jumlah aparatur ini disebabkan beberapa faktor diantaranya seperti banyaknya jumlah pegawai yang pensiun, meninggal dunia tanpa diimbangi dengan penerimaan pegawai baru, dan juga adanya pegawai yang pindah tempat ke kabupaten/kota lain. Dengan semakin menurunnya jumlah aparatur yang ada maka secara otomatis juga akan 
menurunkan kinerja pelayanan aparatur oleh pemerintah terhadap masyarakat. Berdasarkan data yang ada terlihat tingkat pendidikan bahwa tingkat pendidikan pegawai di Kota Jambi dari tahun 2008 sampai dengan tahun 2012 didominasi oleh pegawai dengan tingkat pendidikan SLTA sementara untuk tahun 2013 sampai dengan tahun 2015 terlihat adanya pergeseran yang didominasi pegawai dengan tingkat pendidikan Sarjana. Dengan melihat pergerseran tingkat pendidikan dari para aparatur tersebut tentu akan memberikan perubahan dan perbaikan dalam hal kinerja dari aparatur tersebut dibandingkang tahun sebelumnya. Sehingga dalam melaksanakan tugas dan kewajibannya dapat maksimal dan efisien.

Seiring dengan semakin meningkatnya sumberdaya dari aparatur yang ada diharapakan dapat berdampak pada meningkatnya motivasi kerja dan dari para aparatur yang ada. Kondisi yang ideal untuk tingkat pendidikan pegawai secara umum dimulai dari yang terbanyak jumlahnya adalah sarjana S1, sekolah menengah atas, sekolah menengah pertama, sarjana S2, dan terakhir sarjana S3. Untuk pegawai berpendidikan sekolah dasar seharusnya tidak ada lagi. Pegawai dengan pekerjaan non keahlian seperti pesuruh, seharusnya dipegang oleh pegawai berpendidikan paling rendah sekolah menengah pertama. Sementara untuk pegawai dengan pendidikan S2 dan S3 diperlukan sebagai pembuat kebijakan dan pelaksana kebijakan tersebut adalah pegawai dengan pendidikan sarjana S1 dan sekolah menengah atas disesuaikan dengan posisi jabatan masing-masing. Untuk dapat mencapai kondisi ideal ini maka pemerintah Kota Jambi harus bekerja keras meningkatkan pendidikan pegawai dilingkungannya. Hal ini dapat dilakukan dengan cara memberikan motivasi kepada pegawainya untuk melanjutkan pendidikan melalui pemberian beasiswa, peningkatan anggaran di bidang pendidikan dan lainlain. Pegawai yang berpendidikan sekolah dasar dimotivasi untuk dapat melanjutkan pendidikan ke jenjang yang lebih tinggi dan dilakukan secara bertahap agar ke depan pegawai yang berpendidikan sekolah dasar sudah tidak ada lagi. Jika kondisi ini dapat segera direalisasikan oleh pemerintah Kota Jambi maka kedepan kinerja pelayanan aparatur lebih cepat membaik sehingga rencana pembangunan yang di targetkan juga lebih cepat tercapai dan terlaksana. Untuk lebih jelasnya dapat dilihat pada tabel dibawah ini.

Tabel 4. Jumlah pegawai berdasarkan tingkat pendidikan di Kota Jambi

\begin{tabular}{||c|c|c|c|c|c|c|c||}
\hline Tahun & SD & SLTP & SLTA & DIPLOMA & S1 & S2-S3 & JUMLAH \\
\hline 2008 & 89 & 173 & 1.380 & 549 & 812 & 71 & 3074 \\
\hline 2009 & 89 & 173 & 1.380 & 549 & 812 & 71 & 3074 \\
\hline 2010 & 87 & 158 & 1.634 & 583 & 976 & 108 & 3546 \\
\hline 2011 & 59 & 95 & 978 & 123 & 837 & 107 & 2199 \\
\hline 2012 & 47 & 90 & 825 & 159 & 891 & 97 & 2109 \\
\hline 2013 & 42 & 81 & 1.165 & 253 & 1.290 & 177 & 3008 \\
\hline 2014 & 42 & 79 & 1.169 & 253 & 1.270 & 167 & 2980 \\
\hline
\end{tabular}




\begin{tabular}{||l|l|l|l|l|l|l|l||}
\hline 2015 & 72 & 49 & 745 & 250 & 1.081 & 155 & 2353 \\
\hline
\end{tabular}

Sumber : Kota Jambi Dalam Angka

Berdasarkan tabel diatas secara rata rata pendidikan pegawai yang berpendidikan sarjana di Kota Jambi selama tahun 2008-2015 rata-rata hanya sebesar 40,92 persen dari total aparatur, sementara berdasarkan data $\mathrm{BKN}$, rata-rata aparatur yang berpendidikan sarjana terhadap total aparatur adalah 44,43 persen. Ini berarti aparatur berpendidikan sarjana di Kota Jambi masih berada dibawah rata-rata nasional. Sementara rata rata aparatur yang berpendikan SLTA adalah sebesar 41,14 persen artinya presentase sumberdaya aparatur di Kota Jambi masih ideal.

Namun jika dilihat persentase riel pertahun tingkat pendidikan aparatur di Kota Jambi pada tahun 2012 dan seterusnya sudah ideal karna sudah melebihi standar data BKN, dengan rata-rata aparatur yang berpendidikan sarjana terhadap total aparatur adalah 44,43 persen.

Presentase peningkatan tingkat pendidikan ini terus berlangsung seiring dengan meningkatnya jumlah aparatur yang melanjutkan pendidikannya sehingga akan menurunkan jumlah aparatur yang berpendidikan SLTA kebawah dan miningkatnya Aparatur yang berpendidikan Sarjana (S1,S2 dan S3). Peningkatan tingkat pendidikan dari aparatur mempunyai peran yang sentral mengingat pengetahuan aparatur turut menentukan berhasil tidaknya pelaksanaan tugas yang dibebankan kepadanya. Pegawai yang mempunyai pengetahuan cukup dapat meningkatkan efisiensi pemerintah daerah. Sebaliknya pegawai yang kurang mempunyai pengetahuan cukup maka dalam melaksanakan tugas kurang efisien.

Selanjutnya jika dilihat berdasarkan profesi atau jenis pekerjaan para pegawai yang ada di Kota Jambi maka tenaga guru merupakan jumlah pegawai yang paling banyak di bandingkan tenaga struktural, tenaga kesehatan dan tenaga fungsional lainnya. Berdasarkan data yang ada jumlah pegawai yang bekerja sebagai tenaga pengajar rata rata selama mencapai lebih dari 46 persen sementara untuk tenaga struktural sebesar 35 persen. Tingginya jumlah persentase tenaga pengajar dibandingkan dengan tenaga struktural, kesehatan dan fungsional ini menunjukkan adanya indikasi bahwa pemerintah daerah Kota Jambi lebih serius dalam melakukan perbaikan sumberdaya manusia. Jika kondisi ini terus dipertahankan seiring dengan meningkatkan jumlah aparatur yang ada maka tidak mustahil kedepan akan terjadi peningkatan pelayanan masyarakat dan juga kinerja dari para aparatur juga akan meningkat menjadi lebih baik dari sebelumnya.

Sementara itu aparatur paramedis sebagai sumber daya manusia utama yang dimiliki perlu dibina dan dikembangkan untuk meningkatkan kinerja tenaga kesehatan. Berdasarkan data pada tabel 5.2 jumlah tenaga paramedis hanya mencapai 11-13 persen dari total aparatur. 
Jika dibandingkan dengan jumlah penduduk yang ada di Kota Jambi yaitu sebanyak 576.067 orang pada tahun 2015, maka jumlah tenaga paramedis ini masih sangat minim, dalam artian 1 orang tenaga paramedis melayani \pm 642 orang penduduk di Kota Jambi. Adapun banyaknya jumlah aparatur pegawai negeri sipil di Kota Jambi berdasarkan jenis profesinya dapat dilihat pada tabel dibawah ini.

Tabel 5. Jumlah Aparatur Pegawai Negeri Sipil (PNS) berdasarkan Profesi/Jenis Pekerjaan di Kota Jambi (Tahun 2014 - 2016).

\begin{tabular}{||c|c|c|c|c|c||}
\hline Tahun & Struktural & $\begin{array}{c}\text { Tenaga } \\
\text { Guru }\end{array}$ & $\begin{array}{c}\text { Tenaga } \\
\text { Kesehatan }\end{array}$ & $\begin{array}{c}\text { Fungsional } \\
\text { Lainnya }\end{array}$ & JUMLAH \\
\hline 2014 & 1.023 & 3.950 & 887 & 2.042 & 7.902 \\
\hline 2015 & 1.093 & 4.007 & 897 & 2.033 & 8.030 \\
\hline 2016 & 1.098 & 3.000 & 917 & 1.871 & 6.886 \\
\hline
\end{tabular}

Sumber: BKD Kabupaten Tanjung Jabung Barat

Berdasarkan kodisi yang ada di Kota Jambi dengan menggunakan tiga indikator yang dijadikan ukuran dalam pengukuran indeks kinerja pelayanan aparatur di Kabupaten Tanjung Jabung Barat maka diperoleh hasil pada tabel 5.3 di bawah ini.

Tabel 6. Indeks Kinerja Aparatur Pemerintah Daerah Kota Jambi Tahun 2014 - 2015.

\begin{tabular}{||c|c|c|c|c||}
\hline \hline Tahun & PASTA & PAPTA & PARTA & IKAPD \\
\hline 2014 & 61,87 & 49,98 & 11,22 & 41,023 \\
\hline 2015 & 55,92 & 49,90 & 11,17 & 38,99 \\
\hline Rata rata & 58,89 & 49,94 & 11,19 & 40,00 \\
\hline
\end{tabular}

Sumber data diolah.

Keterangan :

IKAPD $\quad=$ Indeks Kinerja Aparatur Pemerintah Daerah

PASTA $\quad=$ Persentase aparatur sarjana per total aparatur.

PAPTA $\quad=$ Persentase aparatur pendidik per total aparatur.

PARTA $\quad=$ Persentase aparatur paramedis per total aparatur.

Dari tabel diatas terlihat bahwa Indeks Kinerja Aparatur Pemerintah Daerah Kota Jambi rata rata sebesar 40 persen. Berdasarkan kategori yang telah ditetapkan angka ini termasuk kedalam kategori kinerja aparatur baik dari lima kategori yang ada yaitu tidak baik, kurang baik, cukup baik, baik dan sangat baik. Hal ini menunjukkan bahwa kinerja aparatur di Kota Jambi mencapai kondisi yang diharapkan namun masih perlu penanganan dari kualitas atau tingkat pendidikan aparatur lebih di tingkatkan lagi, karena masih dibawah standar nasional yaitu sebesar 44,43 persen. Dari ketiga indikator yang menjadi acuan terlihat bahwa indikator aparatur paramedis memberikan sumbangan terendah dalam menentukan indeks kinerja secara keseluruhan. Rendahnya sumbangan dari indikator ini dikarenakan masih sedikitnya jumlah pegawai paramedis yang ada dilingkungan pemerintah Kota Jambi. 
Selain dari pemerintah daerah, pemerintah pusat juga turut campur tangan dalam meningkatkan kualitas kinerja aparatur seperti melalui ditetapkannya Undang-Undang Nomor 22 Tahun 2004 tentang Pemerintahan Daerah, pasal 133 yang menjelaskan bahwa dalam rangka pembinaan, Pemerintah memfasilitasi penyelenggaraan Otonomi Daerah maka pemerintah mengupayakan pemberdayaan otonomi daerah melalui Pengembangan karir pegawai negeri sipil daerah, mempertimbangkan integritas dan moralitas, pendidikan dan pelatihan, Pangkat, mutasi jabatan, mutasi antar daerah, dan kompetensi. Lebih lanjut menurut UU Nomor 54 Tahun 2003 tentang kepegawaian yang tertuang dalam PP Nomor 101 Tahun 2000 tentang pendidikan dan pelatihan untuk dapat membentuk sosok Pegawai Negeri Sipil seperti tersebut diatas perlu dibina melalui pendidikan dan pelatihan (diklat) yang mengarah kepada peningkatan mutu, kemampuan dan perbaikan kepribadian pegawai itu sendiri. Dengan upaya tersebut maka diharapkan ke depan kinerja pelayanan aparatur pemerintah di ota Jambi akan lebih baik lagi.

Kinerja Pelayanan Publik.

Penyelenggaraan pelayanan publik yang dilakukan oleh pemerintah juga masih dihadapkan pada sistem pemerintahan yang kurang efektif dan efisien serta kualitas sumber daya manusia aparatur yang belum maksimal. Hal ini terlihat dari masih banyaknya keluhan dan pengaduan dari masyarakat baik secara langsung maupun melalui media massa. Pelayanan publik perlu dilihat sebagai usaha pemenuhan kebutuhan dan hak-hak dasar masyarakat. Sementara kondisi saat ini, masyarakat mulai tidak puas dengan pelayanan yang ada. Kodisi ini merupakan bentuk dari semakin menurunnya kepercayaan masyarakat, jika hal ini tidak segera diatasi maka akan menciptakan kondisi yang kurang baik antara pemerintah dan masyarakat.

Dari hasil pengolahan dengan menggunakan alat analisis Indek Kinerja Pelayanan Publik (IKPP), menggunakan tujuh indikator yaitu Daya Tampung SD dan SMP (DTSDP), Rasio Murid SD dan SMP per Guru (RSDPG), Daya Tampung Siswa SLTA (DTSLA), Rasio Murid SLTA per Guru (RSLAG), Ketersediaan Fasilitas Kesehatan (KFK), Ketersediaan Tenaga Kesehatan (KTK) dan Kualitas Infrastruktur (KI) maka diperoleh hasil sebagai berikut.

Tabel.7 Indeks Kinerja Pelayanan Publik Kota Jambi Tahun 2008 - 2015.

\begin{tabular}{|c|c|c|c|c|c|c|c|c|r|r|}
\hline $\begin{array}{c}\text { TAHU } \\
\text { N }\end{array}$ & DTSD & $\begin{array}{c}\text { DTSLT } \\
\text { P }\end{array}$ & $\begin{array}{c}\text { DTSLT } \\
\text { A }\end{array}$ & $\begin{array}{c}\text { RSD } \\
\text { G }\end{array}$ & $\begin{array}{c}\text { RSLP } \\
\text { G }\end{array}$ & $\begin{array}{c}\text { RSLA } \\
\text { G }\end{array}$ & $\begin{array}{c}\text { KF } \\
\text { K }\end{array}$ & KTK & KI & IKPP \\
\hline 2008 & 235,20 & 307,55 & 281,68 & 16,79 & 12,20 & 11,98 & 1,37 & - & $\begin{array}{r}23,5 \\
8\end{array}$ & $\begin{array}{r}158, \\
1\end{array}$ \\
\hline 2009 & 235,13 & 301,38 & 321,12 & 16,29 & 12,38 & 12,35 & 1,45 & - & 23,5 & $\begin{array}{r}162, \\
8\end{array}$ \\
\hline 2010 & 235,10 & 306,48 & 320,60 & 16,82 & 13,56 & 12,76 & 1,22 & - & 83,5 & 163, \\
2
\end{tabular}




\begin{tabular}{|r|r|r|r|r|r|r|r|r|r|r|}
\hline 2011 & 233,3 & 318,47 & 321,60 & 10,55 & 13,58 & 12,21 & 1,32 & - & 55,0 & 170, \\
0 & 2 \\
\hline 2012 & 239,96 & 318,47 & 321,60 & 16,60 & 13,58 & 12,21 & 1,38 & - & $\begin{array}{r}63,9 \\
3\end{array}$ & \multicolumn{1}{l}{171,} \\
\hline 2013 & 255,93 & 317,71 & 318,98 & 18,44 & 15,95 & 14,91 & 1,39 & - & 4,7 & 173, \\
\hline 2014 & 258,09 & 327,07 & 325,66 & 17,97 & 15,03 & 13,29 & 1,43 & 15,61 & 2 & 0 \\
\hline & & & & & & & & & 75,3 & 157, \\
2015 & 258,09 & 327,07 & 328,07 & 17,08 & 14,29 & 13,75 & 1,28 & 15,57 & 2 & 3 \\
\hline
\end{tabular}

Sumber Data di olah

Pada tabel diatas terlihat bahwa sepanjang 8 tahun terakhir indeks kinerja pelayanan publik mengalami fluktuasi. Dengan fluktuasi yang terjadi pada pelayanan publik ini secara tidak langsung menunjukkan bahwa adanya ketidak konsistennya pemerintah Kota Jambi dalam membangun dan menentukan kebijakan sebagai upaya penyediaan fasilitas pelayanan publik. Ketidak konsistenan ini sangat dipengaruhi oleh bermacam-macam faktor, seperti; bergantinya pemegang kekuasaan, perubahan anggaran belanja daerah, prioritas pembangunan, dan kesalahan dalam pengambilan kebijakan serta masih rendahnya sinkronisasi perencanaan.

Berdasarkan data yang ada pada tabel diatas secara rata rata nilai indek kinerja pelayanan publik adalah sebesar 164,19, dengan kriteria sangat baik. Meskipun indeks pelayanan publik di pemerintah Kota Jambi, masih banyak yang perlu ditingkatkan dan diperbaiki terutama dalam hal etika dan kecakapan dari aparaturnya.

Sudah saatnya pemerintah mereformasi pelayanan publik dengan menggeser pola penyelenggaraan pelayanan publik dari yang semula berorientasi pada penyelenggara dengan kekuasaan kepada kebutuhan masyarakat umum yang berorientasi kepada kepuasaan pemberian pelayanan.

Tabel 8 Analisis SWOT di Kota Jambi

\begin{tabular}{|c|c|c|}
\hline Faktor Faktor internal & Kekuatan (Strengths) & Kelemahan (Weaknesses \\
\hline Faktor Faktor Eksternal & - Jumlah PNS yang banyak & $\begin{array}{l}\text { - Kualifikasi pendidikan belum mencukupi } \\
\text { - Kualitas SDM masih kurang } \\
\text { - Sarana dan prasarana masih kurang } \\
\text { - Motivasi kerja pegawai masih rendah } \\
\text { - Jumlah pegawai kurang memadai }\end{array}$ \\
\hline Peluang (Opportunities) & Asumsu Strategi SO & Asumsi Strategi WO \\
\hline $\begin{array}{l}\text { - Dukungan pemerintah daerah } \\
\text { - Koordinasi dan kerjasama } \\
\text { yang baik } \\
\text { - Perubahan peraturan undang } \\
\text { undang yang membuka } \\
\text { peluang baru dalam } \\
\text { bekerja }\end{array}$ & $\begin{array}{l}\text { - Memberikan kesempatan kepada } \\
\text { seluruh PNS untuk } \\
\text { mengembangkan } \\
\text { profesionalisme dan } \\
\text { produktivitas setinggi tingginya } \\
\text { - Melakukan koordinasi yang baik } \\
\text { dengan pemerintah daerah dalam } \\
\text { upaya mendukung program } \\
\text { kegiatan yang berorientasi pada } \\
\text { pelayanan publik } \\
\text { - Meningkatkan kinerja melalui } \\
\text { peningkatan honorarium sesuai } \\
\text { dengan kan minganan } \\
\text { prosedur dan kewenangan yang } \\
\text { ada untuk meningkatkan kinerja } \\
\text { pelayanan publik }\end{array}$ & $\begin{array}{l}\text { 1. Peningkatan koordinasi dan sinkronisasi program } \\
\text { dengan sektor lain dalam pendayagunaan aparatur } \\
\text { 2. Percepatan pembangunan dan pengembangan sarana } \\
\text { dan prasarana SIMPEG yang mampu mendukung } \\
\text { kebijakan dalam pengelolaan sumberdaya aparatur } \\
\text { 3. Peningkatan akses pegawai terhadap kebijakan dan } \\
\text { informasi pengelolaan SDM Aparatur } \\
\text { 4. Mendorong peningkatan pemanfaatan jasa lembaga } \\
\text { kediklatan yang tersedia } \\
\text { - Memberikan pembinaan pada PNS agar } \\
\text { meningkatkan profesionalisme } \\
\text { Pendidikan dan pelatihan bagi PNS sesuai dengan } \\
\text { bidangnya } \\
\text { - Memanfaatkan dukungan pemerintah daerah untuk } \\
\text { lebih menumbuh kembangkan potensi yang } \\
\text { dimiliki organisasi dan pengadaan sarana dan } \\
\text { prasarana penunjang pelaksanaan tugas }\end{array}$ \\
\hline
\end{tabular}




\begin{tabular}{|c|c|c|}
\hline & & $\begin{array}{l}\text { - Melakukan koordinasi dan kerjasama yang baik } \\
\text { dalam upaya meningkatkan motivasi kerja, } \\
\text { disiplin dan kinerja pegawai } \\
\text { - Intensifkan koordinasi dengan bupati dan semua } \\
\text { SKPD dalam rangka rekruitmen pegawai yang } \\
\text { handal }\end{array}$ \\
\hline Ancaman (Threats) & Asumsi Strategi ST & sumsi Strategi WT \\
\hline $\begin{array}{l}\text { 1. Situasi politik nasional dan lokal } \\
\text { (dalam komitmen pengembangan } \\
\text { SDM Aparatur) } \\
\text { 2. Belum pulihnya kepercaya } \\
\text { masyarakat terhadap aparatur } \\
\text { 3. Semakin kritisnya pola pi } \\
\text { masyarakat } \\
\text { 4. Pengelolaan manajemen sumberda } \\
\text { manusia di daerah lain } \\
\text { 5. Globalisasi (transparasi, akuntal } \\
\text { pengelolaan SDM } \\
\text { 6. KKN } \\
\text { 7. Apatisme dan ketidakpercayaan da } \\
\text { masyarakat } \\
\text { 8. Kompetisi antar pegawai yang terbata }\end{array}$ & $\begin{array}{l}\text { - Penegakan hukum dan aturan } \\
\text { dengan sebaik baiknya } \\
\text { - Penempatan pegawai sesiai dengan } \\
\text { keahliannya } \\
\text { - Memanfaatkan pendidikan dan } \\
\text { pelatihan untuk meningkatkan } \\
\text { skill pegawai dalam menghadapi } \\
\text { perkembangan dan penguasaan } \\
\text { teknologi } \\
\text { - Melakukan pembinaan dan } \\
\text { evaluasi kinerja pegawai } \\
\text { - Memanfaatkan kewenangan yang } \\
\text { ada untuk memperbaiki kinerja } \\
\text { oorganisasi } \\
\end{array}$ & $\begin{array}{l}\text { - Meningkatkan kompetensi dan produktivitas PNS } \\
\text { agar mendapat kepercayaan dari masyarakat } \\
\text { - Meningkatkan memampuan SDM dalam menguasai } \\
\text { teknologi melalui pendidikan dan pelatihan dan } \\
\text { penyediaan sarana dan prasarana penunjamg } \\
\text { - Melakukan upaya memotivasi dan mendisiplinkan } \\
\text { pegawai agar kinerja dan produktivitas meningkat } \\
\text { - Menyesuaikan rekruitmen pegawai dengan } \\
\text { kemampuan dan skill yang dibutuhkan }\end{array}$ \\
\hline
\end{tabular}

\section{Kesimpulan Dan Saran}

\section{Kesimpulan}

1. Bahwa Kinerja Pelayanan aparatur pada pemerintah Jambi sangat baik. Hal ini didasarkan pada nilai rata rata dari indeks nilai ideal pada setiap indikator, berdasarkan data Badan Kepegawaian Negara (BKN) tahun 2013

2. Bahwa Kinerja Pelayanan Publik pada pemerintah Kota Jambi juga sangat baik. Hal ini didasarkan pada kategori pelayanan publik yang berada diatas nilai ideal

Saran

Berdasarkan kondisi kinerja yang ada di Kota Jambi saat ini maka beberapa hal yang perlu ditingkatkan pemerintah dalam upaya meningkatkan kinerja aparatur di Kota Jambi adalah sebagai berikut:

1. Memberikan kesempatan dalam eksplorasi diri bagi para pegawai baik melalui pelatihan dan pendidikan kejenjang yang lebih tinggi.

2. Menerapkan reword dan punisment bagi para pegawai

3. Meningkatkan akses pegawai terhadap kebijakan dan informasi pengelolaan SDM aparatur.

4. Penempatan pegawai sesuai dengan keahliannya (profesionalisme).

5. Memberikan motivasi dan pembinaan yang lebih terstruktur

6. Melakukan rekruitmen sesuai dengan bidang keahlian yang dibutuhkan. 


\section{DAFTAR PUSTAKA}

Ahmad Djojosugito, 2001, Kebijakan Pemerintah Dalam Pelayanan Kesehatan Menyongsong AFTA 2003, Pusat Data dan Informasi PERSI, Jakarta.

Anggarini, Y dan Puranto, H. 2010. Anggaran Berbasis Kinerja, STIM YKPN, Yogyakarta.

Renstra Pembangunan Kesehatan 2005 - 2009, Departemen Kesehatan Republik Indonesia, Jakarta.

Bastian, Indra. 2006. Sistem Akuntansi Sektor Publik, Edisi 2. Salemba Empat. Jakarta.

Deputi IV BPKP. 2005. Pedoman Penyusunan Anggaran Berbasis Kinerja (Revisi). Jakarta: BPKP.

Gomes, Foustino Cardoso (2001). Manajemen Sumberdaya Manusia, PT.Andi Offset, Yogyakarta

http://Meilanikasim's blog.com/2012/05/06/Masalah Pendidikan di Indonesia.

http://Suryanto/2009/03/31/Pendidikan Murah dan Efisiensi Biaya Pendidikan.

Instruksi Presiden Nomor 7 Tahun 1999 tentang Akuntabilitas Kinerja Instansi Pemerintah (AKIP) Jakarta

Jurnal Akademika, Fisip Untad Vol.06 N0.01 ISSN 1411-3341, Februari.2014

Keputusan Kepala Lembaga Administrasi Negara Nomor 239/IX/6/2003 tentang Perbaikan Pedoman Penyusunan Laporan Akuntabilitas Kinerja Instansi Pemerintah.

Laksono Trisantoro, 2005, Good Governance dan Sistem Menjaga Mutu Pelayanan Kesehatan, Surabaya.

LAN-RI., (2000). Sistem Administrasi Negara Republik Indonesia, Lembaga Administrasi Negara Republik Indonesia (LAN-RI), Jakarta

Mudrajad Kuncoro, 2004. Metode Riset untuk Bisnis dan Ekonomi: Bagaimana Meneliti dan Menulis Tesis, Erlangga, Jakarta.

Mustazir. N, 2003, Membangun Sistem Jalan Raya yang Efektif Dalam Mendukung Pengembangan Wilayah, Seminar Nasional, Jambi.

Pusdiklatwas BPKP.2007. Akuntabilitas Instansi Pemerintah. Edisi 5. Jakarta.

Putranto. Iwan Edi, 2000, Pokok-Pokok Pikiran Peran Serta Masyarakat Dalam Pembangunan, Majalah Jalan dan Transportasi, Jakarta.

Rangkuti, F., 2005. Analisis SWOT Teknik Membedah Kasus Bisnis, Cetakan ke-12, PT.Gramedia Pustaka, Jakarta.

Salusu, J., (2003). Pengambilan Keputusan Stratejik, Untuk Organisasi Publik dan Organisasi Nonprofit, Grasindo, Jakarta. 
Sinambela. 2006, Reformasi Pelayanan Publik Teori, Kebijakan dan Implementasi, Bumi Aksara, Jakarta.

Sugiyono, 2012, Metode Penelitian Kuantitatif Kualitatif dan R\&D, Alfabeta, Bandung.

Sukirno, Sadono, 1999, Makroekonomi Modern, PT. Raja Grafindo Persada, Jakarta.

Sulastomo, 2005, Menjaga Mutu Pelayanan Kesehatan, Pustaka Sinar Harapan, Jakarta.

Todaro, M. 1997, Pembangunan Ekonomi. Penerbit Erlangga. Jakarta.

Widyantoro, Ari Eko. 2009. Implementasi Performance Based Budgeting: Sebuah Kajian Fenomologis. Tesis. Semarang: Program Pascasarjana Fakultas Ekonomi Universitas Diponegoro. 